\title{
Geminin as an Emerging Anticancer Drug Target
}

\author{
Shashank Kumar* \\ Department of Biochemistry and Microbial Sciences, Central University of Punjab, India
}

Submission: October 21, 2016; Published: October 27, 2016

*Corresponding author: Shashank Kumar, Department of Biochemistry and Microbial Sciences, Central University of Punjab, India, Email: shashankbiochemau@gmail.com.

\section{Editorial}

For normal cell division, one time replication origin firing is mandatory. The mutual interaction and levels of Cdt1 and geminin (GMNN) proteins are known to be involved in this regulatory mechanism. Imbalance between these protein levels may cause defects in replication of DNA leading to genome instability. This might cause cancer. In different stem cells, such as leukemic and hematopoietic stem cells, significant levels of GMNN have been recorded. It has been observed that siRNA mediated GMNN suppression can arrest cancer cell proliferation without affecting the normal cells. Two molecules of GMNN and one molecule of Cdt1 form a heterotrimer, and two heterotrimer combines and form heterohexamer which inhibits the DNA licensing process. Any moiety that is able to inhibit the formation of GMNN-Cdt1 heterohexamer might act as regulatory source and could be utilized as a DNA replication inhibitor in cancer cells (Figure 1).

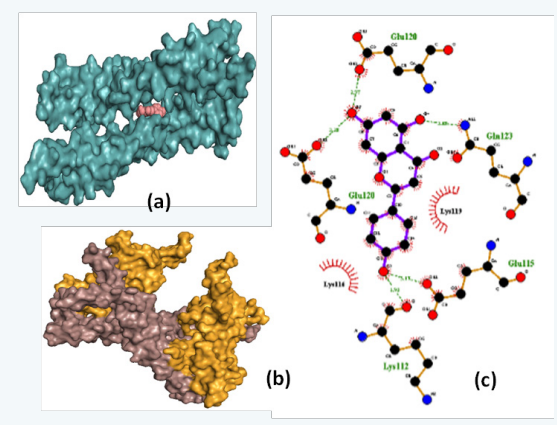

Figure 1: a) Surface structure showing interaction of apegenin (salmon color) with GMNN (deapteal color) heterotetramer.

b) GMNN (dark salmon color) Cdt1 (tv-orange color) heterohexamer complex.

c) Lig-plot of GMNN and apigenin interaction showing Hydrogen bond interaction.

DNA replication induction and DNA damage mediated apoptosis are the mechanism behind GMNN activity suppression mediated cancer cell proliferation arrest [1,2]. It has been reported that GMNN is associated with different diseases including cancer. GMNN have been found to associate with regulation of apoptosis, regulatory proteins of cell cycle, cell proliferation markers, signaling molecules and extracellular matrix moieties [3]. Proliferation and labeling index are the two parameters that are used to measure dividing cells in particular tumor and mitotic activity of a cell population respectively. The proliferation and labeling index of GMNN is associated with different clinicpathological profiles of cancer patients [4]. Differential expression of GMNN is associated with different types of cancer and poor prognosis of cancer patients. Recently following facts about GMNN involvement in cancer pathophysiology has been reviewed by Kushwaha et al. [1].

- It is associated with high grade and ER-negativity in breast cancer

- It is an independent indicator of poor prognosis and overall survival, breast cancer metastasis and invasiveness.

- Its level is positively correlated with tumor grade and has negative correlation with lymph node metastases.

- It could be a valuable marker for tumor aggressiveness in salivary gland carcinomas as well as possible prognostic marker in gastric and other carcinomas/sarcomas.

- $\quad$ Labeling index of GMNN with other proteins could be a reliable tool for the differential diagnosis of malignant meso-thelioma and reactive mesothelial cells.

- GMNN ratio with other proteins is known to determine G1 phase stretch and modulation of cell proliferation.

Keeping in mind GMNN as an anticancer drug target some studies has been designed and executed its role in cancer treatment. Treatment of pancreatic cancer cell lines with apegenin (a phytochemical) showed decreased GMNN expression [5]. In a clinical study a well known anticancer drug imagine treatment showed up regulation of GMNN protein in triple negative breast cancer patients. Some studies indicated that GMNN might act as an oncogene and involved in failure of cytokinesis, aneuploid 
production and tumor aggressiveness. These properties make GMNN a worth full therapeutic target against cancer aggressiveness [6]. Thus GMNN can act as a novel prognostic and diagnostic biomarker for cancer and might be a future anticancer drug target.

\section{References}

1. Kushwaha PP, Rapalli KC, Kumar S (2016) Geminin a multi task protein involved in cancer pathophysiology and developmental process: A review. Biochimie 9084(16): 30220-30226.

2. Zhu W, DePamphilis ML (2009) Selective killing of cancer cells by suppression of geminin activity. Cancer Res 69(11): 4870-4877.

3. Cates JMM, Memoli VA, Gonzalez RS (2015) Cell cycle and apoptosis regulatory immunoreactivity in low-grade myxofibrosarcoma and myxoma. Virchows Arch 467(2): 211-216.
4. de Andrade BA, León JE, Carlos R, Delgado-Azañero W, MosquedaTaylor A, et al. (2013) Expression of minichromosome maintenance 2, Ki-67, and geminin in oral nevi and melanoma. Ann Diagn Pathol 17(1): $32-36$

5. Salabat MR, Melstrom LG, Strouch MJ, Ding XZ, Milam BM, et al. (2008) Geminin is over expressed in human pancreatic cancer and down regulated by the bioflavonoid apigenin in pancreatic cancer cell lines. Mol Carcinog 47(11): 835-844.

6. Markey M, Siddiqui H, Knudsen ES (2004) Geminin is targeted for repression by the retinoblastoma tumor suppressor pathway through intragenic E2F sites. J Biol Chem 279(28): 29255-29262.
Your next submission with JuniperPublishers will reach you the below assets

- Quality Editorial service

- Swift Peer Review

- Reprints availability

- E-prints Service

- Manuscript Podcast for convenient understanding

- Global attainment for your research

- Manuscript accessibility in different formats ( Pdf, E-pub, Full Text, Audio)

- Unceasing customer service

Track the below URL for one-step submission http://juniperpublishers.com/online-submission.php 